\title{
1. China and the modern world
}

The shift to the modern world took its initial form in Europe, where a unique constellation of economic, social, cultural and political processes ushered into being the world of natural science, industry, states, nations and mass societies. The form of life was dynamic, evidencing both domestic intensification and global expansion, and when the representatives of this culture, in particular traders, reached China, the demands of this insurgent culture slowly undermined the long-established, agrarianbased bureaucratic feudal system centred upon the emperor. The collapse of the system was slow, and European powers were crucial players with their insistent demands for free trade. The Chinese elite's eventual choice of some variant form of modernity was signalled by the 1911 Revolution, but in the event the revolution was beset by problems: there were internal divisions, a continuing foreign presence and finally civil war and outright foreign military invasion. The elite's embrace of modernity only found effective form in the 1949 Revolution, and the long process of collapse and recovery is now available in contemporary nationalist terms as the century of humiliation, a notion that unpacks to call attention to foreign aggressions and domestic failings and draws the lesson of the importance of national development - altogether, an era which, more positively, ended with the creation of New China.

It is the nature of the shift to the modern world that informs the logic of politics in China. The argument presented here will contextualize contemporary Chinese politics in this fashion, granting that the present is the out-turn of events in the past and turning to spell out institutional forms (the party-state), politico-cultural understandings (the national past, collective memory and the realms of everyday life) and patterns of policy action (ideas-in-practice). Together, these are the frameworks of contemporary debates amongst political players in China.

$* * * * * * * *$

The notion of the shift to the modern world encompasses a number of elements. The modern world revolves around the rise of natural science based industry, the creation of a system of states, the invention of nations and the rise of mass popular politics. The shift to the modern world 
entails complex social change, and the process is open-ended; it is not a one-time event, and its dynamics continue to run, and whilst its broad future development is clear, its particular detailed character is not determined in advance. The process began in Europe. It was the result of a fortuitous set of circumstances, and Europe was remade from the inside, and later the rest of the world was variously remade. In the nineteenth and early twentieth centuries these processes assumed the form of the creation of state-empire systems, followed later by system dissolution and the creation of new states. But these processes were not mechanical, and each episode of domestic change was discrete, just as each episode of external expansion was also discrete; so particular logics of change must be deciphered, as each country's shift to the modern world is unique.

In respect of China, the task of deciphering these logics of change is crucial as these long and unfolding historical processes underpin and give shape to the current politics. The past both shapes the present and offers the cultural resources whereby both past and present can be reflexively understood. This means that characterizations cast in the terms of outsiders will only have limited reach; it is the internal logic that must be grasped. So the research process is dialogic as sets of ideas are put to use, replies made and new material presented and new formulations advanced. The research process is also reiterative and open-ended, debates are renewed and reworked and rarely definitively settled. In this text, using the materials of historical institutionalism, the concern is to offer a simple, short, realistic characterization of the domestic logic of contemporary politics in China.

\section{HISTORICAL INSTITUTIONALISM AND CULTURE CRITICAL WORK: AN APPROACH TO POLITICAL ANALYSIS}

Scholars have produced a number of ways of approaching generic political analysis: ${ }^{1}$ political philosophy (reflection upon abstract concepts); political history (records and reflections upon political events); political institutions (characterization and discussion of formal systems of political organization); political ideology (formal and informal programmes of parties and other agents); and, in contrast, political behaviourism (measuring aspects of political behaviour and subjecting the resultant data sets to statistical analysis, thus, parties, elections and voting patterns). 
Each offers some valuable material, and each set of resources can be put to work and offer some insight into the nature of political life. However this text will use the strategies of historical institutionalist analysis $^{2}$ and culture critical work. The approach draws on elements of all the above and allows analysts to uncover the ways in which institutional machineries and ideas (organizational forms plus associated habits of thought plus ways of working plus strategies of legitimation within wider publics) have developed over time. Such institutional machineries are understood to be contingent creations, and they serve to order political life in particular ways, but they are not fixed, they are part of a deeper dynamic. As structural conditions shape the behaviour of agents, and the behaviour of agents in turn impacts structural dynamics, then the ways in which agents read their structural circumstances find expression in institutional machineries. And as structural circumstances change, so agents respond and thus institutions are reworked. The process is open-ended, but it is not without overall shape, and this is determined by the ongoing unfolding shift to the modern world, driven by the demands of natural science based industrial capitalism, states (and wider state systems), nations and popular politics.

\section{Historical Institutionalism}

Historical institutionalism has developed a particular repertoire of strategies of enquiry:

- case studies of particular countries (or parts of countries);

- historical studies of long-term patterns (of continuity and change);

- comparative analysis of the ways in which different countries have tackled the demands of the modern world;

- interpretation of patterns of understanding of key groups.

Historical institutionalism has developed a particular intellectual vocabulary:

- path dependency - institutions tend to run along lines set by the past;

- episodes of change - disturbances (external or internal) create crises and provoke change;

- punctuated equilibrium - societies work but are not static, that is, they are generally stable but liable to relatively abrupt change. 


\section{Culture Critical Work}

Culture critical analysis has developed around a small number of central concerns:

- language - unpacking the relationship of human language and human practice;

- ideology - unpacking the social class-inflected nature of ordinary language;

- discourse - unpacking the routinization of ways of understanding and acting.

Culture critical analysis has developed a number of specialist intellectual vocabularies:

- hermeneutic elucidation of texts;

- anthropological/sociological elucidation of the ideas informing social practices;

- critical discussion of contemporary cultural practices (text analogues).

Together, these strategies of enquiry and their related concepts allow scholarly analysts to track the long-term historical development trajectories of countries, to uncover their changing institutional forms, to consider changing ways of understanding and to detail present politicocultural circumstances. The ensemble of concepts points not to a collection of methods, rather a way of thinking. ${ }^{3}$ Contemporary political and policy debates amongst elites and masses can thus be understood to be rooted in the unfolding development of the countries themselves, and, of course, it is within the framework of inherited institutions and inherited culture that the resources necessary to guide further change will be found.

\section{THE LONG HISTORY OF CHINA RECALLED}

The shift to the modern world in China was triggered by the demands of foreign traders in the nineteenth century, and their behaviour was aggressive, involved routine recourse to violence and was justified in terms of ideologies claiming beneficial results from trade. ${ }^{4}$ These were the earliest agents that drew China into the nineteenth century global system of state-empires; however, China had existed for much longer, 
and one familiar way of grasping the history is to speak in terms of dynasties, but this is just one way of thinking about the country, its history and ways of living.

\section{Grasping the Outlines of China}

There are numerous ways of grasping the historical trajectory of a country, the mix of past, present and implied future:

- China as a culture - the history is presented in terms of a sequence of dynasties running back two thousand years;

- China as a geographical term - home to a number of polities over that same period with internal patterns and external borders shifting and changing;

- China as a race-nation - a nationalist tale mixing claims about race, racial origins, dynasties, foreign aggression, humiliation ${ }^{5}$ and contemporary success;

- China in the eyes of hostile foreigners - critical tales specifying varieties of imminent economic and political failure; ${ }^{6}$

- China as a dynamic modern polity - with a domestic pattern of power and a definite place within the international system, the whole represented in public discourse in terms of a national past, the whole accessible to historical social scientific analysis. ${ }^{7}$

It is this last noted China that will be discussed here; in particular, its unfolding historical trajectory as it shifts into the modern world, a world which is itself continually changing its nature, an ongoing collective project.

\section{Pre-modern or Traditional $^{8}$ China}

After the modern world had arrived in the guise of foreign traders and related empire builders, soldiers, missionaries and so on, and had precipitated change, sometimes serving trade (hence the Treaty Port System), sometimes generating social problems (opium sales and growing addiction), and in other places precipitating unforeseen and unforeseeable chaos (Taiping Rebellion), Chinese reformers in the late nineteenth century borrowed terms from Japan in order to grasp the nature of the modern world, the world that had presented itself in the guise of rapacious demands from foreigners for trading rights, hence the concepts of nation and state and democracy. A clutch of other terms entered elite discourse around this time, later feeding into elite and 
popular practice, thus race. In brief, around the turn of the twentieth century, an idea of China as a nation, rooted in a distinct race, with its own state and the overall goal of democracy, began to take root. ${ }^{9}$

Today's China is therefore a recent construction, and the claims of nationalists to the effect that China - in these senses - is rooted in the long, distant past are quite false. The same argument, of course, is true of European and American polities; indeed, in general, social scientists offer quite different understandings of national identities from those offered by nationalists. ${ }^{10}$ So, prior to the arrival of the modern world and the early moves to reconstruct the country, China, as we would now say, operated quite differently.

Pre-modern (traditional) ${ }^{11}$ China operated as:

- a cultural sphere - those people who could read and write the Chinese script, those people who were conversant with classical texts and those people who were educated in these matters;

- an economic trading sphere - those people living in the mainland with its three macro-regions (northern around the Yellow River, eastern around the Yangtze River, and southern oriented towards the Pearl River), along with those people linked by trading networks, overland the Silk Road to the north and west, and by sea the trading networks along the coast plus those reaching down into the Nanyang;

- an international political sphere - those polities distinct from China which were nonetheless influenced by China, in particular, Korea, Japan and Vietnam, and worked within a definite relationship with China, tributary relationships or broadly the Sino-centric system;

- a social/cultural sphere - individual Chinese were embedded in the social world in terms of a number of spheres including family, kin groups, clan groups, place of origin and language groups, and then wider concerns were grasped via Buddhism, Taoism, Confucianism and the emperor system;

- a governance sphere - the imperial system of a core, plus provinces, examinations and a Confucian social hierarchy (emperorscholars-soldiers-peasants-merchants).

These characteristics sum up the diversity of forms of life found in pre-modern China. The point here is that pre-modern China was a rich and diverse civilization, it functioned and its character was quite different from equivalent cultures in Europe. Its character today is in part a product of those historically accumulated characteristics; again, quite different from Europe. 


\section{Cores and Peripheries}

The geographical extent of China understood as a polity has varied down the centuries. The territorial extent of the polity has waxed and waned, and at the present time, with the People's Republic of China (PRC), the country is near to its maximum historical size. China occupies a large geographical space, has a large population and has complex domestic politics. Institutionally the party-state system works as a hierarchy of descending/ascending cores and peripheries. ${ }^{12}$ The unitary state unpacks as provinces, townships, villages and so on, so power is not spread evenly amongst geographical areas or populations. The capital city occupies the core position and thereafter there are distinct powerful subordinate cores and equally distinct subordinate peripheries. The pattern is changing somewhat as, in addition, government policy over recent years has favoured urbanization; thus cities are becoming increasingly powerful, economically, culturally and politically.

In the past, in pre-modern China, whilst there were powerful urban cores - economic, cultural and administrative - these tended to be closely integrated with peripheral agricultural areas. In pre-modern China cities did not display the distinctiveness associated with European cities of the same era. ${ }^{13}$ China retained large areas of peasant farming, and as late as the turn of the twentieth century, the vast bulk of the population were farmers, living in rural areas. On this, Stockman comments that at the time of Mao's death only 20 per cent of the population lived in urban areas. ${ }^{14}$

In the present, in modern China, the crucial cores are cities, powerful economic, cultural and political centres. Today the linkages of these cities are not only domestic but also international, and there are three main sub-regions around Beijing, Shanghai and Guangzhou. The creation of this pattern can be detailed with nineteenth century patterns (reflecting the opening period of the shift to the modern world, thus, the impact of foreign traders and the creation of the 'Treaty Port System'), the early twentieth century patterns (reflecting the developments of the Nationalist era and the destruction of war), the early period of the Chinese Communist Party (CCP) where rural development was favoured, and then, finally, the current pattern, the creation of the period of reform and opening up, with large cities plus the accumulated impacts of CCP policy in respect of rural and urban development. Urban development is now, in the twenty-first century, a stated goal of the party-state, one aspect of the party's plans for the next stage of development. 


\section{THE IMPACT OF THE MODERN WORLD}

Karl Marx and Frederick Engels wrote approvingly of the dynamism of capitalism, and they alluded to the experience of China, with capitalism battering down all Chinese walls and with this dynamism opening the way to progress capitalist style: ${ }^{15}$

The bourgeoisie, by the rapid improvement of all instruments of production, by the immensely facilitated means of communication, draws all, even the most barbarian, nations into civilization. The cheap prices of its commodities are the heavy artillery with which it batters down all Chinese walls ... It compels all nations, on pain of extinction, to adopt the bourgeois mode of production; it compels them to introduce what it calls civilization into their midst, that is, to become bourgeois themselves.

The particular individual vehicles of these structural processes were traders. There had been early contacts from the mid-sixteenth century but the traders arrived in numbers in the nineteenth century. The British and French, in particular, sought trading rights and were not averse to using violence to advance their interests; nonetheless, recent commentators have argued that the Qing authorities had no clear idea who these people were or what they wanted. ${ }^{16}$

\section{Foreign Traders, Domestic Problems and the Collapse of the Qing}

Structural change requires that agents read and respond. Commentators suggest that the Qing failed to grasp the nature of the threat posed by foreign traders. China entered the modern world in a quite distinctive fashion, and the arrival of foreign traders signalled change; these traders were the early representatives of a form of life new to the Chinese elite, mercantile capitalism. European powers had been trading in the region for many years, thus the Portuguese established Malacca in 1511 and Macau in the mid-sixteenth century, and their activities fitted into established East Asian networks of trade, but later traders offered opportunities and made demands that the extant system could not accommodate. The key incoming players were the French and British, and other foreign groups also participated in the new mercantile capitalist trade.

China was the goal for both powers, and both approached from the south; the British traded at Canton in the Pearl River Delta, whilst the French traded from bases in Indo-China. The key players were the British, characterized by one scholar as a rapacious, violent and disreputable group, ${ }^{17}$ and for many years they were a mystery to the 
authorities in Beijing, who could not understand who they were, why they were violent or what they wanted. ${ }^{18}$ The British traded opium, the Qing authorities resisted, and the First Opium War followed. Hong Kong was established. A second trading base was established in Shanghai, and later the Second Opium War led to further bases being established. The Qing authorities had to address domestic problems, deal with aggressive traders and seek to understand the form of life which underpinned their activities, and the Qing authorities slowly failed. The 1861-95 SelfStrengthening Movement, the 1898 Hundred Days Reform and the later Boxer Rebellion all failed to stop the operation or extension of the Treaty Port System, as China was reduced to a quasi-colony of the Europeans, Americans and Japanese. ${ }^{19}$

\section{The 1911 Revolution and Civil War}

The scale of foreign depredations was clear by the last years of the nineteenth century. Qing era attempts at reform had not succeeded, and the Boxer Rebellion underscored the weakness of the authorities as scholars and political activists sought new ideas and new models. Japan was one model where the success of the Meiji Restoration was noted; ideas and information also flowed into China from Europe and America along with traders, settlers, missionaries, administrators and so on. All these available materials had to be read into Chinese culture, and new vocabularies were needed; thus state, nation, race, democracy and so on. These ideas fed into local debates, and one aspect was the notion of humiliation: that China had been brought low by its own weakness and the activities of foreigners. ${ }^{20}$ But by now the Qing authorities had numerous opponents: regional, social class, popular and intellectual. ${ }^{21}$ Moore $^{22}$ comments that by the time the Qing authorities realized the extent of required reforms it was already too late.

The 1911 Revolution began with a dispute about the control of railway infrastructure, where the Qing authorities sought to assert central control and local groups resisted. These disputes began in Wuhan in Hubei Province as local army personnel rebelled. The Qing authorities were repudiated and the rebellions spread until a provisional government was proclaimed in January 1912. The difficult task of creating a new political settlement was begun; that is, the proclaimed republic had to gather support from other regional elites and the mass of the population. The initial drive to create a republic ran from 1912 to 1913, and a double process followed: the republic government in the south was unable to assert its authority over the rest of the country and the Qing residues in the north could not sustain their position and gradually faded from the 
scene. In the period 1913-16 one key figure from the late Qing era - the soldier Yuan Shikai - assumed power, and the leaders of the republic acquiesced. Yuan then proclaimed himself emperor, but he died in 1916 and a political void opened. The failure of the republic left local forces in control of local areas, and the bulk of the country was controlled by warlords, some three hundred plus, with half a dozen major groups, and these groups fought numerous wars, some involving armies measured in the hundreds of thousands. ${ }^{23}$ The result, predictably, was great confusion.

\section{Chiang Kai Shek and the Nanjing Decade}

The early death of Sun Yat Sen in 1925 saw power within his party shift to the military leader Chiang Kai Shek, who worked to unify the republican forces. He made an alliance with the Communist Party and opted to solve the problem of warlords via a mixture of military campaigns, co-option and bribery. And in 1926 he launched the Northern Expedition. Moving up from the south of China towards Shanghai and Nanjing, Chiang's armies were successful as warlords were defeated or fell in line. The Communist Party in Shanghai, anticipating his arrival, organized an uprising amongst their supporters in the industries of the city - workers - the closest the city had to a conventional Marxist proletariat, but Chiang did not support the efforts of his erstwhile allies; indeed, he took the opposite course as his troops along with the forces of local industrialists and city gangsters attacked and largely destroyed the Communist Party forces, actions that provoked the Chinese Civil War.

Over the next decade, the Nanjing Decade, running up to 1937, developments unfolded along three distinct trajectories. First, Chiang continued to move his forces northwards and, using the same techniques as before, organized a kind of unity for the country. The capital was based in Nanjing, the country was unified, and it began to put in place the apparatus of a modern state and to wind back the privileges of the foreigners. Then, second, Chiang began a series of military campaigns designed to extirpate the remnants of the Communist Party, and a number of campaigns were launched against communist rural base areas. In time the base area organized by Mao was overrun; the remnants fled in a long retreat over difficult ground in remote areas of China before eventually finding a form of sanctuary in the far north of the country. And then, third, in 1937 the Japanese invaded China and the human and material losses were severe; further chaos followed. The civil war resumed at the end of the Pacific War, and the CCP secured a rapid military victory. Mao declared the founding of the PRC, and the remnants of the nationalists fled to Taiwan. 


\section{Mid-century Warfare}

The slow decay and eventual collapse of the Qing dynasty was followed not by the modern republic of the revolutionists' designs but instead by waves of violence as warlords fought numerous wars and nominally modern political parties/movements fought a civil war. A newly created state-empire launched a military invasion, and American and European powers were drawn into a Pacific War. This in turn was subsumed within the wider Second World War, which in turn was followed by the nascent, cold war inflected final phase of the civil war. ${ }^{24}$ The results of all this for China were catastrophic, and the number of deaths can be put at around 30 million or so - add to that the injured, the material destruction and the reactions and memories of those, the majority, who survived.

These episodes are read into contemporary official politico-cultural understandings; different memories have been stressed at different times:

- Kuomintang (KMT) government ideas in the 1930s of legacies of national humiliation;

- the KMT's claims to a New China;

- the CCP's creation of the idea of 'the long march';

- the CCP's (nationalist) claim to have led national resistance to Japanese invaders;

- the CCP's (nationalist) embrace of national humiliation and antiJapanese rhetoric.

The government of Xi Jinping celebrated the Seventieth Anniversary of the end of the Pacific War with a large military parade in Beijing, and thus the CCP laid claim to a central role in the military victory.

\section{The PRC}

The CCP came to political power in China in the wake of a series of wars including civil war, inter-state war and regional war, and finally world war. The consequences of these conflicts for China were severe in terms of casualties, material losses and social disorder. It is unsurprising that when the CCP came to wield political power that its first concerns were not dissimilar to those of more straightforwardly post-colonial regimes: security, order and development. Domestically, first the CCP had to deal with the remnants of the nationalist forces and their sympathizers amongst the population, landlord and business classes. At that time, 90 per cent of the population was rural, so landlords were particular targets. Estimates of the numbers killed often say around a million. Second, the 
CCP had to construct its party-state apparatus and draw in the population, mobilizing and disciplining them to the CCP's politico-cultural project. And third, the CCP sought development, and the project was cast in local terms. The CCP leadership advanced an amalgam of ideas including Marxism-Leninism as a framework, hence, class, class conflict, progress, along with Chinese nationalism, here a celebration of country, culture and people, taken as evidenced during the war years plus a celebration of the vitality of the peasantry and the possibilities inherent in that energy.

The early period 1950-56 was successful: foreign interests were expelled, the country unified, and a reform programme begun; rural areas were reorganized, with landlords disposed and peasants given land; and urban areas were reorganized as private property was progressively curtailed. The development record was good, but inevitably there were problems. Early on the CCP invited criticism - the Hundred Flowers Campaign - but critical debate was quickly closed down in the AntiRightist Movement, and intellectuals and professions were demobilized, expertise rejected. The later 1958-60 Great Leap Forward (GLF) was an elite-sponsored attempt to skip stages of development, with mass mobilization as the key, but it failed and famine resulted. ${ }^{25}$ Mao was sidelined and experts reasserted their ideas. Subsequently, Mao mobilized support amongst students and used them to attack the apparatus of the CCP. It was understood by participants as an attempt to remake culture, the ways in which people thought, hence the Cultural Revolution. The conflict continued until it began to threaten the army, the core of the state, at which point the revolution was halted; yet the elite-level political conflicts continued, and the death of Mao was crucial, for now elite-level power balances shifted as those closest to Mao were arrested and given a show trial as Deng Xiaoping took control.

The contemporary institutional system inherits this history plus the impacts of state-empire systems plus the more enduring cultural residues of pre-modern China. Today China is a dynamic modern polity, but it has a distinctive form: the country is geographically sub-continental, the party-state system is a distinctive double bureaucracy/hierarchy and the elite are committed to national development; in all, a variant developmental state.

\section{Reform and Opening}

The new leadership inaugurated a new programme, in effect learning from the experience of East Asia, and their approach was pragmatic. In the period 1978-84 reforms were carried out in agriculture and a number of Special Economic Zones (SEZs) were set up. In agriculture 
the process was one of de-collectivization with the household responsibility system, and the results were dramatic; agricultural output rose and levels of living improved. At the same time, rural industry was encouraged, and it took the form of Township and Village Enterprises (TVEs), low-level production oriented towards an open market that soaked up surplus labour and generated a perhaps modest economic surplus. In the period 1984-87 urban industry and finance were reformed, but this proved to be more difficult to organize as the economic and social make-up of a city was more complex than that of a rural area. Individual enterprises were given more autonomy and moved towards open-market operation - again, a process of liberalization. There were many issues to address: the notion of private ownership, issues of transferring ownership from state to reformed enterprises, questions of financing and managing quasi-private enterprises, and problems of building up liberal-type welfare operations. These experiments adopted one novel form, that is, SEZs, and five were created on coastal sites. One was adjacent to Hong Kong in Shenzhen, and the area prospered, so too the other SEZs. However, the country suffered the stresses and strains of rapid change, and popular discontent was made clear in June 1989. ${ }^{26}$ Deng Xiaoping's 1992 Southern Tour was designed to reaffirm the policy of reform, and a new policy was established, the 1992 programme of creating a socialist market economy. Further sweeping reforms followed, and in 2001 the country joined the World Trade Organization (WTO). This signalled the country's participation within the global economic system, and a species of finally achieved complete success was celebrated at the 2008 Beijing Olympics. ${ }^{27}$

The elite has pursued the goal of economic advance pragmatically and single-mindedly, and the policy is now more than 30 years old and has produced dramatic economic and social changes. Economic advance has been headlong, and material levels of living have improved, but there have been difficulties as inequality and corruption have grown, and there are severe environmental problems. In this period the party-state system has reformed and adapted, ${ }^{28}$ and contrary to the expectations of unsympathetic foreign critics, it has not collapsed.

\section{CHINA: INSTITUTIONAL FORMS AND POLITICO-CULTURAL UNDERSTANDINGS}

China entered the modern world via a long experience of quasi-colonial rule. From the early nineteenth century through to the opening years of the twentieth, the nature of Chinese politics - institutions and ideas - was 
shaped by the exchange with foreigners, and the Qing regime was slow to react and in time was displaced. The earliest attempts at a coherent and effective response to the foreigner-carried demands of the modern world came with the Republican Revolution, but this failed and was followed by civil war, with the domestic situation made much worse by inter-state warfare. Matters were finally brought under domestic political control with the establishment of the PRC. A new political settlement was put in place, ${ }^{29}$ a matter of institutional machineries and ways of understanding that together carried new domestic power relations, official ways of understanding, along with projects looking forward.

\section{Standard Social Science Strategies of Analysis}

Debates about the nature of politics in China are not new, as both domestic and foreign scholars have written extensively. In regard to recent, that is, modern-era work, two rough characterizations can be offered: domestic work is cast in terms of 'worrying about China', ${ }^{30}$ whilst foreign material has been cast in terms of the resources of the social sciences, and in the post-Second World War period this last noted has been heavily influenced by work done by American scholars, itself shaped by the environment of cold war, and cast negatively in terms of the party-state.

Flemming Christiansen and Shirin Rai review analyses of the party-state: ${ }^{31}$

- the party-state is totalitarian and so the entire economic, social and political system is controlled by one ideologically motivated repressive party;

- the party-state system is dominated by an elite but elite control is fissured by continual manoeuvring for position and advantage, that is, the party-state is nominally well ordered but in fact is riven with factionalism and clientelism; ${ }^{32}$

- the party-state system is a complex bureaucracy and the system is essentially bureaucratic with decisions taken inside the system and handed down;

- the party-state system enshrines some fundamental traits of Chinese culture, in particular, the common social practices of hierarchy and obedience.

The first of these - totalitarianism - belongs to the less plausible habits of thought of the cold war. David Shambaugh ${ }^{33}$ offers a sophisticated example of this conventional analysis. He reviews a number of major 
American China scholars looking at post-1989 China, and the discussion is cast in terms of 'the comparative lens of Leninist systems'. ${ }^{34}$ Such work has a deep expectation of uni-linear movement towards a liberaldemocratic future, and in this perspective the PRC party-state might escape inevitable breakdown, but only via repression or muddling through, and its best chance is to become authoritarian and corporatist, maybe with some liberal-democratic aspects, like Singapore or Hong Kong. ${ }^{35}$ The problem with this sort of analysis is clear: it is uni-linear (modernization/globalization), it is doubly un-reflexive (the USA is the unspoken ethico-political model and the unspoken context for the discussion) and it belongs to the cold war era (now over); but thereafter, to be clear, the author opts (sensibly) for atrophy and adaptation, thus the party-state system is losing support but is adapting.

It might be noted that these cold war style habits of thought are recognizable in contemporary American (or Western) commentary, with publicly voiced anxieties about PRC military expenditures, publicly voiced concerns about PRC's domestic human rights record (dissidents or death penalty or Tibet and so on), and publicly voiced China-related concerns for governance of the global economy (debates around the Trans-Pacific Partnership (TPP) or Asian Infrastructure Investment Bank (AIIB) or International Monetary Fund (IMF) rules), thus recently summer 2015 - publicly voiced anxieties about the condition of the economy of China.

Then the second - factionalism and clientelism - may have been accurate during the civil war years when the $\mathrm{CCP}$ was under sustained pressure from the KMT and the mix of military and political policies was an urgent matter, that is, a wrong decision in the 1930s could have led to the party's demise, and it may have been accurate during the postrevolutionary period dominated by Mao Zedong, with elite level confusions around the Hundred Flowers episode or GLF or - paradigmatically - during the Cultural Revolution. One instance of the concern for factions and networks is offered by Tony Saich. The analysis looks from the outside and overlaps with the cold war habits noted above - thus: ${ }^{36}$

Personal power and relations with powerful individuals are decisive throughout the Chinese political system and society ... Thus the Chinese political leadership is riddled with networks of personal relationships and is dominated by patron-client ties ... This system ... lends itself easily to the formation of factions within the leadership ... This overdependence on personal relationships makes the Chinese political leadership extremely unstable. 
However, more recently, whilst the post-Mao regimes have been analysed in similar fashion, the party has made efforts to regularize internal elite-level decision making, including elite cadre retirement and elite replenishment, and, of course, with $\mathrm{Xi}$ Jinping, it has launched an unprecedented purge of corrupt party members and officials within the state machine.

Thereafter, the last noted - fourth line - must carry some weight. It is a culturalist approach that appeals to the cultural resources of the Chinese, urging that as humans are social animals, they dwell in communities, shaped by rules handed down, ${ }^{37}$ whilst cultures shift and change, they do so slowly.

Nonetheless, it is the third line - complex bureaucracy - that is the most appropriate line of commentary for present purposes. It is in line with the historical institutionalist approach taken in this text, so the party-state system is best conceived as a double bureaucracy: there is a state bureaucracy/hierarchy with a spread of familiar functions and, for its membership, familiar paths of career advancement; and there is a professional party/hierarchy with its own functions and paths of career advancement. ${ }^{38}$ The two bureaucracies are intertwined, but they have their own views of the world. Picking up this line, a related strategy is offered by Zheng Yongnian, ${ }^{39}$ whose work borrows elements of neoinstitutionalism and neo-Marxism, thus institutions and ideas, and who offers a take on the domestic trajectory and logic of the polity, thus the $\mathrm{CCP}$ is the organizational spine around which debate revolves - it is an 'organizational emperor'.

\section{Double Bureaucracy/Hierarchy - Institutions/Ideas}

China is ordered via a party-state system. The party-state works as a double bureaucracy. Party and state are nominally separate but in practice intermingled, and commentators report that the party is the key player. Larus comments: 'State government and the party have overlapping memberships, and high-ranking government personnel are important CCP leaders. ${ }^{40}$ So, first, the party elite is reported to number around 2,500 and is organizationally centred on the Politburo and its Standing Committee; ${ }^{41}$ second, the party is reported to have a membership of some 80 million $^{42}$ and an elaborate hierarchical structure that reaches down through numerous administrative levels producing around 825,000 ${ }^{43}$ committees of one sort or another, national, provincial, prefectural, municipality, township and village; and third, the machinery of the state comprises a number of organizations, thus the State Council, National People's Congress (NPC), Supreme People's Court, Central Military 
Commission, plus the administrative civil service, plus provincial and local government. ${ }^{44}$

On the machinery of the party, Wang ${ }^{45}$ reports that 'the salient characteristics of the party as an organization are that it is hierarchical, pyramidal, and centralist in nature' and so power is concentrated in the hands of party leaders who operate via the major organs of the party: the National Party Congress, the Central Committee, the Central Commission for Discipline Inspection, the Politburo and its Standing Committee, along with the General Secretary.

The National Party Congress, which convenes once every five years, is the largest meeting of party members, and its primary function is to elect a new Central Committee and a new Central Commission for Discipline Inspection. The Central Committee is, in theory, the supreme authority of the party when the National Party Congress is not in session, and its primary functions are (i) directing the work of the party; (ii) representing the party in its foreign relations; (iii) determining the members of the Central Military Commission; and (iv) electing the Politburo and its Standing Committee, and the General Secretary. ${ }^{46}$

However, the Politburo has 'the ultimate decision-making power concerning war, armed force, and national defence' 47 and its Standing Committee 'works as a kind of inner cabinet and groups together the country's most influential leaders'; 48 its members meet regularly and frequently to discuss issues in different policy areas, and they also conduct fieldwork and observation nationwide, especially when there is an outbreak of crisis or a natural disaster. ${ }^{49}$

Leading Small Groups are set up by the Politburo and its Standing Committee in an ad hoc manner to address special and strategic issues, and they are 'supra-ministerial coordinating and consulting bodies formed to build consensus on some crucial and strategic issues when the existing bureaucracy is unable to do so' ${ }^{50}$ At present, in early 2016, President Xi Jinping is Head of four Leading Small Groups: (i) Leading Small Group on Comprehensively Deepening Reform; (ii) the Central Finance and Economics Leading Small Group; (iii) the Central Internet Security and Informatization Leading Group; and (iv) the Leading Group for Deepening National Defence and Military Reform. ${ }^{51}$ The General Secretary 'is the highest-ranking official of the Party and heads the Politburo and the Standing Committee ... [and is] responsible for convening the meetings of the Politburo and its Standing Committee and presides over the work of the Party Secretariat'. ${ }^{52}$

In addition to these bodies, the Central Commission for Discipline Inspection is important; its tasks are the '(i) maintenance of party morale 
and discipline; (ii) control over the performance of party organizations; and (iii) investigation of breaches of party discipline' ${ }^{53}$

The major organs of the party are shown in Figure 1.1.

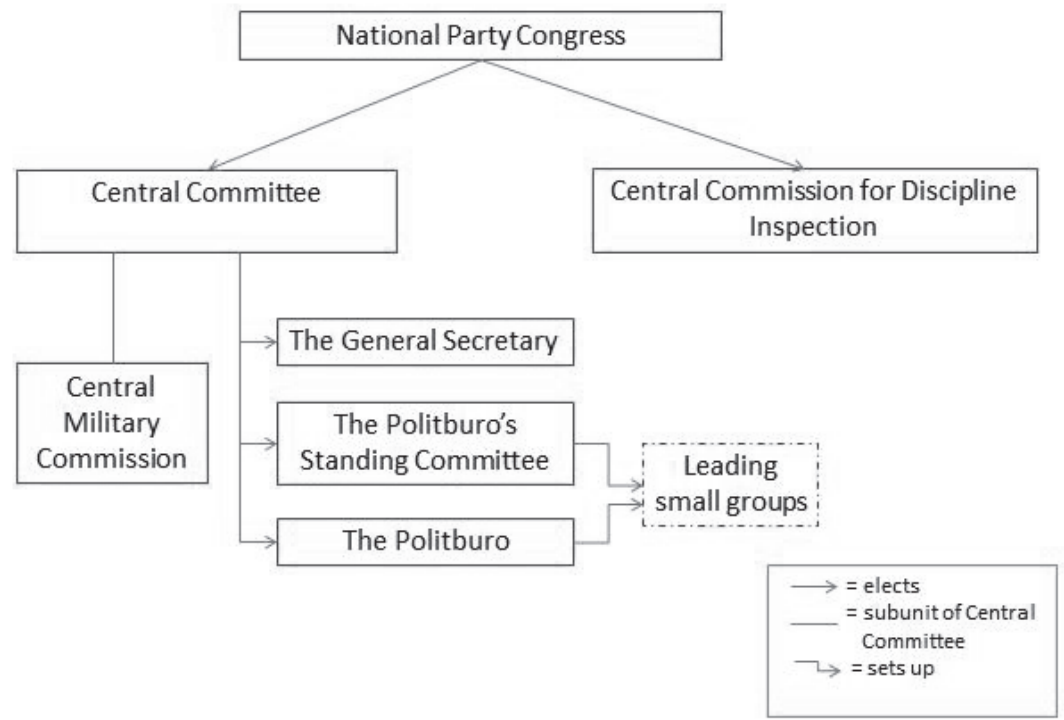

\section{Figure 1.1 The major organs of the Chinese Communist Party}

On the machinery of the state, $\mathrm{Wang}^{54}$ reports that the state comprises a number of organizations, which includes the NPC and its Standing Committee, the State Council, the Central Military Commission, the Supreme People's Court and the Supreme People's Procurator, in addition to a huge bureaucracy.

The NPC, which is the highest organ of state power and the highest legislative body, elects the President and Vice President of the PRC and 'is empowered to amend the constitution, to make laws, and to supervise their enforcement', ${ }^{55}$ and when the NPC is not in session, 'its Standing Committee serves as the executive body to act on behalf of the congress'. ${ }^{56}$ And down the hierarchy, Local People's Congresses, established in provinces, municipalities, counties and townships, are the local organs of state power, and they are empowered to 'adopt and issue resolutions and examine and decide on plans for local economic and cultural development and for the development of public services' ${ }^{57}$

The State Council is the highest executive body headed by the Premier, and its primary functions include (i) enacting administrative regulations and issuing decisions and orders in accordance with the Constitution; 
(ii) formulating the tasks and responsibilities of ministries and commissions subordinate to it; and (iii) directing and administering such affairs as economy, national defence, education, and urban and rural development. ${ }^{58}$

The Central Military Commission, a subunit of the party's Central Committee, is the highest military command body, through which the party ensures control over the People's Liberation Army (PLA), and it is responsible to the NPC and its Standing Committee. Its primary function is 'to appoint and remove military personnel, especially the commanders of the seven military regions' ${ }^{59}$

The Supreme People's Court, which is responsible to the NPC, is the highest judicial organ in the nation, and it 'supervises the administration of justice by the people's courts at various local levels and by the special people's courts'.60 The Supreme People's Procuratorate is responsible to the NPC, and it 'directs the work of the people's procuratorates at various local levels and of the special people's procuratorates' ${ }^{61}$

The state relies on bureaucrats to carry out the administrative and executive functions of the government. Larus comments: 'The size of China's bureaucracy is huge, with bureaucrats at every level of Chinese government ... There are ministries and commissions at the central government level, departments at the provincial level, divisions at the county level, and sections at the township levels.' ${ }^{62}$

The machinery of the state is shown in Figure 1.2.

The party organization is the dominant element, the state machine subordinate. Together they order a hierarchical system, and the party elite in Beijing sit atop this structure; and thereafter, party machinery and state machinery together reach down via provinces, cities, townships and villages into the broad population of China.

\section{Organizational Emperor}

The sum total of the activities of the machinery of the party have been recently summed up in terms of the notion of an organizational emperor, ${ }^{63}$ and the system can be read in terms of institutions and culture. It is top-down, it does adjust and, lately, politically it has drawn in more participants, but it is not oriented towards the goal of liberal democracy, and critical voices and novel social groups are absorbed as the inherited system adjusts.

Zheng Yongnian ${ }^{64}$ attends to the nature of the CCP and, rather than judge the party moralistically (authoritarian, despotic and so on ${ }^{65}$ ), or judge it in terms taken directly from European or American experience (where elections equal democracy and the future is understood in variants 


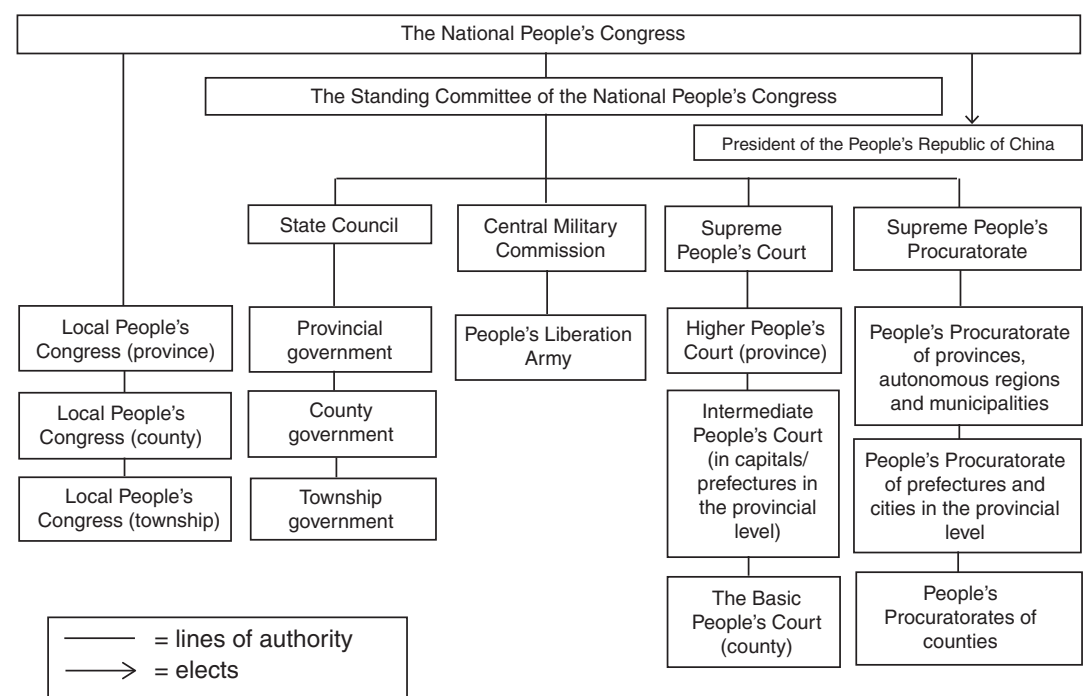

Figure 1.2 The state machinery of the People's Republic of China

of modernization/globalization), asks how does it work? Zheng picks up United States (US) referenced historical/sociological institutionalism (institutional structures of governance shift and change down through time in response to changing external and internal circumstances) along with strands of European Marxism and other contemporary French social criticism in order to make use of the notions of hegemony and discourse; thus institutions change down through time and the agents who animate these systems can only act in line with their understandings and thereafter deploy ideas in order to discipline/mobilize their populations.

Historical and sociological institutionalism opens up issues of understandings and identities; it lets analysts get at how agents understand and act in given circumstances. The line of enquiry can be enriched by the neo-Marxism of Gramsci and the work of French theorists of power/ society (Foucault/Bourdieu), as they variously let analysts get at ways in which elites run arguments within society. The key for the party is continuity and practical adjustment. The organizational emperor embraces the political system and so official obedience is required, but piecemeal change is available (change is within the system, not of the system itself). Using these resources, analysts can get at, first, intra-party and party-state relations and, second, party-state and society relations; that is, how the party orders its affairs and dominates the state and how 
thereafter the party-state machinery dominates society, together revealing how the CCP organizational emperor system works. ${ }^{66}$

Cast in these terms, the CCP is an institutional apparatus that combines historical resources (ways of understanding the machineries of governance inherited from dynastic days) with locally read imported ideas (European Marxism-Leninism) and that has been shaped by the particular historical experience of revolution/civil war; the upshot is a vanguardist Chinese party where the logic runs thus: the elite guides the party in state making and creates a party-state system which thereafter is wedded to the pursuit of development; the Chinese party-state is only a governance institution and so in that sense it is an organizational emperor. The CCP is not a party on a European or American model (that is, lodged in a competitive liberal-democratic party system of governance); rather, it is an organizational emperor: there is only one very complicated structure of governance, the party-state, and the core is the CCP. ${ }^{67}$

Zheng argues that the historical legacy of the emperor system offers resources for the present day. The emperor system was centralized, hierarchical and distant from the population, and it was sustained by ritual and occasional violence. The late nineteenth century added ideas of nation, race, state, party and party vanguard to debates about the polity.

There are two important features of the emperor system: first, it is hierarchical, and this was sustained by a stress on ideological conformity (official truths must be respected); and second, the emperor's power was limited as the core could make rules but all these had to be put into practice by subordinates in the centre and the provinces. Thereafter, in the late nineteenth and early twentieth centuries new ideas were imported and reworked - state, nation, democracy, development and so on - and all were picked up as ways to reorganize China so as to resist foreigners and join in the modern world. But the 1911 parliamentary system failed. The KMT and CCP both moved to the organizational emperor system: an elite-led party-state system oriented to mobilizing the population, either via the KMT system ${ }^{68}$ or CCP system. ${ }^{69}$ However, intra-party democracy in the CCP was weak. In the pre-reform revolutionary and civil war era the struggles amongst the party elite were ruthless and produced a 'winner takes all' style of politics, ${ }^{70}$ but in the post-reform era attempts have been made to institutionalize intra-party politics and today power is more widely distributed. The system is hierarchical and geographically dispersed; there is a nested hierarchy of centres of power; and ritual obedience has to be shown to the CCP emperor, but thereafter individualand institution-based factionalism is rife as factions manoeuvre for position in the party, in the state and in ideology ${ }^{71}$ only the disloyal are rejected. 
Zheng $^{72}$ later discusses elite politics in more direct terms, that is, in terms of factions as they manoeuvre for position and advantage around (i) institutional bases (organizations or offices within the party-state machinery); (ii) policy/ideology (hence all the programmatic statements associated with particular leaders); and (iii) the issue of succession (positioning for change in the direction of the wind). So, with (iii) achieved, then (ii) and (i) are revised accordingly. The post-1949 political history can be read in these terms. The reform era, that is, post-1978, can be read in terms of three phases: first, the Deng Xiaoping era (1978-89); second, the Jiang Zemin era (1989-2002); and third, the Hu Jintao era (2002-12). In each there was a process of power concentration, then new policy and ideological gloss and slogans. Overall, there has been a slow process of intra-party reform, and the key issue of succession is now much more institutionalized (this was not the case in the Mao or Deng periods). And now the leader is Xi Jinping, and commentators note his extensive drive on corruption; and with the September 2015 military parade in Beijing, they also note that he has settled accounts with the important players of the military.

So there are two systems of governance, the party and state, and the relation between the two is crucial; however, the CCP is 'the pillar of the Chinese state'. ${ }^{73}$ Under Mao a central system was created: 'A partycentred political hierarchy was formed: the Party made all decisions over state affairs and the power of the Party at different levels was centralized in the hand of Party secretaries there, and nationwide, all ultimate power was centralized in the hands of Mao Zedong. ${ }^{74}$

After Mao, the paramount leader, Deng Xiaoping, advocated reforms, both economic and political, so there was a discourse of political reform, but the 1989 Tiananmen events stopped these conversations: 'Instead, how to strengthen the domination of the Party over the government is at the centre of reform discourse. ${ }^{75}$

Now the party has a number of important mechanisms. First, the nomenklatura system, whereby the CCP elite controls appointments to very many important posts within the party and the state: ${ }^{76}$ appointments, promotions/relocations, dismissals and retirements. Second, the Central Leading Small Groups, which are party-controlled cross-ministry groups that determine general policy, whilst related State Council Small Groups attend to matters of administration, ${ }^{77}$ and, at lower levels of the hierarchy, there are many similar groups. Third, the Party Core Groups ${ }^{78}$ that oversee work in all government agencies. And, finally, Party Schools ${ }^{79}$ ensure that CCP cadres understand their role. Together these organizations allow the party to control the state. ${ }^{80}$ Thereafter, the party-state asserts power over society. In the pre-reform era all this was very 
centralized, but in the post-reform era there have been changes, with decentralization within the party-state (centre and provinces) and decentralization between the party-state and the wider society by allowing more social groups to form and act. ${ }^{81}$ The party thus secures hegemonic power. The ideas of the party are spread widely through the party-state and through wider society; it is a mix of control plus co-option plus greater tolerance plus nationalism.

All that said, the CCP will change and adapt, as it has in the past, ${ }^{82}$ but the goals built into the CCP apparatus do not point towards a European- or American-style competitive liberal party system. It is true that the CCP has reformed internally and has reformed its involvement with wider society, but it has not moved towards a European or American competitive party system. ${ }^{83}$ The CCP is an organizational emperor and the party is the core of the Chinese political system. It will adjust but not change its core identity $^{84}$ - reforms, yes, and accumulative, drawing in more people and regularizing the procedures inherited from revolution/civil war days, but the core of the emperor system is a commitment to continuity.

$* * * * * * *$

So, overall, the key to the future lies within elite party circles and the associated policy community. The machinery of governance is centred on Beijing. It is organized via the double bureaucracy/hierarchy of the party-state system, animated by the machinery of the party ${ }^{85}$ and legitimated today in terms which call attention both to material advances within the country and an ideology of Chinese nationalism. The party remains the key locus of political life. ${ }^{86}$ It has around 80 million members. In recent years $\mathrm{Xi}$ Jinping has emphasized the importance of the anti-corruption drive and there has been a stress on nationalism, and both find expression in the official media and in social media. The anti-corruption drive has been pursued with great vigour. The related nationalism is often hostile towards the USA and typically virulently anti-Japanese. ${ }^{87}$ Commentators suggest that all this implies that $\mathrm{Xi}$ Jinping's government is, in a sense, conservative, that is, committed to the rule of the party and the continuing international rise of China. ${ }^{88}$

\section{THE PRC IN THE TWENTY-FIRST CENTURY: ACHIEVEMENTS AND CONTEMPORARY ISSUES}

All this material may seem remote from contemporary politics, but historical institutionalism looks at the ways in which the past runs into 
the present day, not merely institutional forms but also sets of ideas institutional practices and sets of ideas shape political life.

\section{Reforming the State-Socialist System}

The state-socialist system sought to embrace all aspects of the lives of its citizens, drawing them into productive work, social exchanges and the government of the country via local party and state representatives. It was an ambitious programme, and there was much scope for flexibility in the translation of theory into practice; or, to put it another way, the historical trajectory of the country shaped internal organization, and explicit directions from the state were but one aspect of the mix, ideological convictions on the part of the elite being, in turn, one element of that particular mix. That said, a party-state system was created. Once in place, thereafter, in pursuit of reform, disentangling all these elements in pursuit of a programme of liberalization was never going to be easy: it required the creation of a marketplace (law, regulators, firms and consumers); it required the creation of social welfare systems (health, schooling, housing, accessed now as citizens); it required the reordering of society (the ideologically motivated reconstruction of inherited or traditional patterns of social action was relaxed, old forms allowed to resurface and new marketplace-oriented interactions allowed, in sum, Chinese tradition plus new individualism); and it also involved formal political reforms, so the state-party apparatus adjusts, new categories of members are recruited, administrative structures are reformed and public legitimation shifts from ideological exhortation rooted in the experience of war and revolution towards practical achievement, that is, material advance, plus a reasserted nationalism. Problems remain with corruption amongst the elite, official and corporate sectors. Problems remain with administrative reforms. Problems have emerged with nationalism, which the elite find useful but which can also assume virulent anti-foreigner forms, in particular amongst Internet users where it appears to be an aggressive nationalism rather than a celebration of place and people. ${ }^{89}$ Notwithstanding these problems, there has been much success.

\section{Adopting the Model of the Developmental State}

The reform programme inaugurated cautiously in the late 1970s and early 1980s is usually associated with the leadership of Deng Xiaoping, and whilst the initial impetus to reform may have been domestic, that is, an elite level rejection of the voluntaristic politics of the Cultural Revolution, the overall model of reform, the recipe, so to say, was found in the 
record of the countries of the wider East Asian region, a set of experiences summed in terms of the notion of the developmental state. The term identified a novel strategy of governing the economy, one where the key decision-making group consisted of elite-level officials, supported thereafter by business leaders and politicians, with the triangle of power holders united in the pursuit of national development, that is, carving out a larger space within the global economy and distributing the benefits widely throughout the population within the territory that they controlled. The contrast is with the goals written into then current ideas of liberal markets and modernization, which cast the state as a neutral rule-maker whose job was to facilitate the piecemeal accumulative growth of a global rule-based and self-regulating marketplace. The latter project-cum-economic space was dominated at the time by the USA, but the debate between the goals of national development or liberal market development goes back to Europe in the late nineteenth century, when theorists argued that late developers needed a powerful, nationally oriented state in order to compete with the dominant British free-traders. All these debates have run on for decades, and in this text they can be revisited later - in chapters 4 and 5 - as events, along with newer debates, have unfolded in East Asia. ${ }^{90}$

The reform programme has produced dramatic results, and hundreds of millions have seen their levels of living significantly improved. The keys to this record have been the cities adjacent or linked to the coast: the Pearl River area, the Yangtze River area and the Yellow River area; all these areas have created a powerful manufacturing export machine, and the country enjoys trade surpluses with the European Union, the USA and others in the Global South. The Beijing authorities have come under pressure from their various trading partners to curb these surpluses, but they persist. More generally, the authorities in Beijing face four interlinked tasks: first, replicating the coastal success story in the western or inland parts of China; second, upgrading the economy so that it operates in higher-value-added manufacturing, an aspect of escaping the 'middle income trap'; third, upgrading the financial system and also internationalizing the currency; and fourth, reorienting the economy from exports and infrastructure towards private consumption. These, it might be noted, are problems consequent upon success; thus the economic record is marvellous and standard agency data record the success. As noted above, hundreds of millions have seen their levels of living raised, with rough estimates suggesting that around 300 million now count as middle class citizens. 
Yet, there are also many problems. There is corruption amongst elite cadres/officials, lower-level officials and corporate sectors; overinvestment in infrastructure; wasteful duplication as provinces and cities compete for infrastructure projects; environmental degradation; a weak rule of law (which finds expression in part in mass incidents or rightful resistance ${ }^{91}$ ); and there is inequality between coastal and western or inland China, which feeds inward migration to the cities and, in turn, creates problems, thus the growth of 'villages-in-the-city', homes to communities of migrants. ${ }^{92}$

\section{Collective Memory and the National Past}

The idea of collective memory was presented by the scholar Maurice Halbwachs, ${ }^{93}$ and it points to the ways in which individuals located within groups turn events into memory and pass these memories down to succeeding generations. Collective memory can be carried in families, communities, organizations and so on, and these resources serve to lodge people within the flow of time and are part of the wider stock of ideas carried within a culture, and thus they are available to interpret novel experiences. Halbwachs points to the dispersed nature of collective memory. It is dispersed through the social world in general. However, there are other aspects to this matter, in particular, the role of the state, and here a related idea can be presented, developed by the scholar Agnes Heller. ${ }^{94}$ Heller points to the way in which the production of memory is located within a definite social world: a social world shaped by the demands of modernity, a social world shaped by the modern bureaucratic rational state and a social world shaped by differences in social class. The diversity is brought into some sort of focus via the promulgation by the state of an idea of the nation: who its people are, where they have come from and where ideally they are going. This set of ideas can be summed as 'the national past'; it is always provisional, always contested, and like collective memory, it is always in the process of construction and reconstruction.

China's route to the modern world was chaotic and violent. ${ }^{95}$ The long-established pre-modern empire of the Qing was undermined over the period of the nineteenth century by European, American and Japanese traders; traders who helped establish a species of colonial rule over parts of the country. There were multiple conflicts from the early nineteenth century down to the years following the end of the Pacific War. The end of the Chinese Civil War, ${ }^{96}$ with its attendant outside involvement, was followed by further conflicts, both domestic and international with the cold war. All this gets fed into the contemporary collective memory and 
finds expression in the national past, where some events are remembered, others carefully forgotten, and over time these self-understandings accumulate material. ${ }^{97}$ The material is selective as some events are read in, whilst others are read out. ${ }^{98}$ One aspect, noted by Callahan, ${ }^{99}$ is the official embrace of the notion of national humiliation, a reading of the history of the country, one widely disseminated through schooling and the media, that urges citizens to help build the country in the face of ever dangerous and unscrupulous foreign powers.

\section{International Relations within the Region}

Beijing is the core of the Chinese system, but it would be foolish to treat the polity as a single homogenous entity: ${ }^{100}$ there are multiple factions within the elite levels located in Beijing, there are multiple peripheral agents located in provincial capitals, there is a nascent civil society (much of it web based) and, as the country is very large, there are many local communities with their own local concerns. The country revolves around the party-state apparatus; there is also an officially sponsored nationalism, and it revolves around the construction of the Han race and a stylized national past cast in terms of the depredations of foreigners and national humiliation. The nationalism also revolves around claims to a long history of civilization. Together, these domestic factors feed into the international relations of the country, the policy elite's self-understandings and understandings of others - the party-state authorities speak of socialism with Chinese characteristics, they speak of a socialist market economy, and they speak of peaceful rising or peaceful development.

Today China faces a number of crucial problems in the international relations arena: first, the long-running issue of relations with Taiwan; second, the equally long-running issue of the relationship with Japan; third, relatedly, their relationship with the USA; and fourth, the issue of the South China Sea.

\section{CONCLUSION: AN AGENDA FOR THE DISCUSSION IN THIS TEXT}

The discussion presented here will have roughly the following shape:

- the collapse of the Qing Empire and the creation of the nationalist Republic of China (ROC)

o the failure of the Qing; 
o the rise of domestic resistance and mooted alternatives;

o the Republic Revolution;

- the creation of the PRC

o Mao's peasant revolution;

o Deng's reform programme;

o the emergence of today's China;

- the situation in contemporary China

o domestic politics;

o international politics;

o future politics.

The discussion will offer an interpretive analysis of the logic of politics in China; it will be informed by the resources of historical institutionalism (and cognate ways of thinking) and will identify the crucial institutional structures, the party-state, along with the patterns of thought associated with these institutions, the ways in which inherited resources find expression in elite politics, public policy and the wider, stilldeveloping public sphere, the arena of popular participation.

The text will set aside familiar characterizations of China's politics authoritarian, communist, and so on - as such characterizations belong to a now defunct cold war era; it will also set aside their counterparts, those texts offering varieties of China-boosting; instead, it will offer an analysis grounded in a distinct intellectual approach and addressed to those concerned with a straightforward and realistic account.

\section{NOTES}

1. For a review of recent English-language work in political science and international relations, see Colin Hay 2002 Political Analysis: A Critical Introduction, London, Palgrave.

2. For a review of recent English-language work, see V. Lowndes and M. Roberts 2013 Why Institutions Matter: The New Institutionalism in Political Science, London, Palgrave.

3. A point nicely made by Zheng, Yongnian 2010 The Chinese Communist Party as Organizational Emperor: Culture, Reproduction and Transformation, London, Routledge, p.xv.

4. On the nineteenth century expansion of European (and later American) state-empires: on Britain, see Julia Lovell 2011 The Opium War: Drugs, Dreams and the Making of China, London, Picador, Robert Bickers 2011 The Scramble for China: Foreign Devils in the Qing Empire 1832-1914, London, Allen Lane, Carl Trocki 1999 Opium, Empire and the Global Political Economy: A Study of the Asian Opium Trade 1750-1950, London, Routledge, Brian Inglis 1979 The Opium War, London, Coronet; on France's role, see Bickers 2011; and on the post-1945 record, see R. Kedward 2005 La Vie en Bleu: France and the French since 1900, London, Allen Lane and see chapter 13, Robert Gildea 2002 'Myth, Memory and Policy in France since 1945 ' in J.W. Muller ed. Memory and Power in Post-war Europe, Cambridge University Press; on the late-comers America, Germany 
and Japan, a classic exercise in comparative analysis was given by Barrington Moore Jr. 1966 The Social Origins of Dictatorship and Democracy: Lord and Peasant in the Making of the Modern World, Boston, Beacon Press - see in this context his chapter on China.

5. The mix of celebration of a long civilization plus remembered 'humiliation' by foreigners is pursued by W.A. Callahan 2010 China: The Pessoptimist Nation, Oxford University Press.

6. Available from the nineteenth century down through the cold war and on into the present day - see, for example, in the first, China as the 'sick man of Asia', in the second, China as a 'totalitarian communist dictatorship' and, more recently, China as a 'fragile superpower' (S. Shirk 2007 China: Fragile Superpower, Oxford University Press).

7. To be clear, China's route to the modern world has created a distinctive contingent result: territorially, it is a sub-continent; organizationally, it is ordered by a Beijing-oriented hierarchical double bureaucracy (the party-state), and then there are further provincial cores and peripheries; and thereafter the system as a whole is further inflected by personal networks, factions and so on - or in brief, 'China' is not the name of a neat and tidy nation state. The point is nicely made by Gail Hershatter 2007 'Forget Remembering: Rural Women's Narratives of China's Collective Past' in C.K. Lee and G. Yang eds. Re-envisioning the Chinese Revolution, Stanford University Press, pp. 70-1 - thus 'For scholars, "China" is a convenient shorthand, a way of organising our teaching, our production of knowledge, and our narrative of the nation ... Our persistent habit of talking about "China", however, obscures the extent to which all socialism is local. The working out of state policies is contingent upon geography, prior social arrangements, local personalities, and a host of endlessly variable factors.'

8. The notion of 'traditional' would be useful except for the prevalence within European and American thinking of ideas of 'modernization/globalization theory' where traditional societies are taken to be static, un-dynamic, superstitious and so on, none of which is true of pre-modern China (or, it could argued, anywhere else, see C. Bayly 2004 The Birth of the Modern World 1780-1914, Oxford, Blackwell), and where the end point of the posited process of modernization is exemplified by the contemporary West, or the USA in particular; see W.W. Rostow 1960 The Stages of Economic Growth, Cambridge University Press and F. Fukuyma 1992 The End of History and the Last Man, London, Hamish Hamilton, and on American nationalism, see A. Lieven 2004 America Right or Wrong: An Anatomy of American Nationalism, London, Harper Collins.

9. P.K. Crossley 2010 The Wobbling Pivot: China since 1800, Chichester, UK, WileyBlackwell, pp. 155-63.

10. A trio of classics: B. Anderson 1983 Imagined Communities, London, Verso; E. Gellner 1983 Nations and Nationalism, Cambridge University Press; E. Hobsbawm 1990 Nations and Nationalism since 1780, Cambridge University Press.

11. By traditional is meant China-before-the-modern-world - the detail of pre-modern China has to be specified - and historical institutionalism can do this - what is not meant by 'traditional' is anything like the simple oppositions of 1950/60s modernization theory.

12. The relationships of cores and peripheries is complex - the key issue for politics has been between concentrated power at a single centre (today, unitary state) versus dispersed power amongst a number of centres (today, a notion of federalism, or in China's recent past, warlord territories - on this see Crossley 2010).

13. X. Ren 2013 Urban China, Cambridge, Polity.

14. N. Stockman 2000 Understanding Chinese Society, Cambridge, Polity, p. 57.

15. K. Marx and F. Engels ([1847] 1986) 'The Manifesto of the Communist Party' in Karl Marx and Fredrick Engels: Selected Works in One Volume, London, Lawrence and Wishart, p. 39.

16. Bickers 2011- who is highly critical of these traders.

17. Bickers 2011.

18. Lovell 2011. 
19. As the nineteenth century ran its course, the number of foreign 'concessions' grew these are listed in R. Nield 2015 China's Foreign Places: The Foreign Presence in China in the Treaty Port Era, 1840-1943, Hong Kong University Press.

20. Callahan 2010 pp. 34-6 dates the discourse to the 1920s - May 4th/New Culture; it was picked up by Chiang Kai Shek, then from 1937 to 1990 disregarded, only reanimated after Tiananmen Square Incident 1989.

21. Regional (China was divided - north/south, rural/urban); social class (language, clan, economic position); popular (ethnic division, Manchu/Han); intellectual (conservative, reformer, insurrectionist, revolutionary). On the multiplicity of divisions within Chinese society, see Crossley 2010, chapters 1 and 3; see also Stockman 2000.

22. Moore 1966.

23. On the wars of the warlords, see S.C.M. Paine 2012 The Wars for Asia, Cambridge University Press; see also E.L. Dreyer 1995 China at War 1901-1949, London, Longman.

24. Thereafter, from 1949 there were extensive exercises in 'mopping up' pockets of resistance - as with the end of the war in Europe, so also in China, the violence continued before stability was re-established.

25. P. Short 2004 Mao: A Life, London, John Murray, pp. 476-504 puts the number of deaths at 25 million.

26. David Shambaugh 2008 China's Communist Party: Atrophy and Adaptation, University of California Press analyses the nature of the Communist Party in China and concludes that it has learned the lessons of the 1989-91 period - that is from 4 June 1989 through to the collapse of the Soviet Union; the party has analysed the collapse in systemic terms, that is, a moribund party presiding over an old fashioned isolated economy plus imperial overstretch and US hostility, and taken steps to upgrade the party's organization and performance in governance - successfully; amusingly, the text is grounded in cold war bloc-think and does not ask the question of how Soviet Union and China 'watchers' ever got themselves into the intellectual dead end they came to occupy.

27. Callahan 2010 p. 8 notes that holding the games in China were first mooted in 1908 , as a way of combating national weakness. Callahan adds that the domestic meaning of the games was one of final recovery from a long list of humiliations.

28. Shambaugh 2008.

29. The civil war came to a nominal end when the KMT elite fled to Taiwan; however, civil wars do not come to neat and tidy ends, rather the reverse: they come to slowly drawn out unpleasant ends - for example, the years following the American Civil War or the British elite suppression of the Chartists or the Communist Party of the Soviet Union's suppression of opponents or Franco's suppression of the left-wing and so on. In China the CCP pursued its opponents for several years, with many casualties.

30. G. Davies 2009 Worrying about China: The Language of Chinese Critical Enquiry, Harvard University Press.

31. F. Christiansen and S. Rai 1996 Chinese Politics and Society: An Introduction, Hemel Hempstead, UK, Prentice Hall Europe, pp. 2-22.

32. A position spelled out by T. Saich 2004 2nd ed. Governance and Politics of China, London, Palgrave, see chapter 4, pp. 92-5.

33. Shambaugh 2008 .

34. Shambaugh 2008 p. 13.

35. Shambaugh 2008 p. 175.

36. Saich 2004 p. 95.

37. Z. Bauman 1976 Culture as Praxis, London, Sage, characterizes the realm of ordinary life in terms of the idea of culture-as-praxis.

38. The CCP is not a party in the liberal-democratic sense; China does not have multiple parties, it does not have party competition, it does not have competitive elections as a mechanism for recruiting personnel for positions, but is better grasped as a bureaucracy its focus is not administration, it is politics (mainstream European parties in recent years have been characterized by their 'professionalism' and remoteness from populations, so there are some similarities). 
39. Zheng 2010.

40. Elizabeth Freund Larus 2012 Politics and Society in Contemporary China, Boulder, CO, Lynne Rienner Publishers, p. 108.

41. Cited in K. Brown 2014 The New Emperors: Power and the Princelings in China, London, I.B. Tauris, p. 20.

42. R. McGregor 2012 The Party: The Secret World of China's Communist Rulers, London, Penguin, p.xx.

43. McGregor 2012 p.xi - see diagram of The Party.

44. The machinery is detailed in Saich 2004, see chapters 5 and 6.

45. J.C.F. Wang 2002 7th ed. Contemporary Chinese Politics: An Introduction, Upper Saddle River, NJ, Prentice Hall, p. 70.

46. Larus 2012 p. 110.

47. L.R. Sullivan 2012 Historical Dictionary of the Chinese Communist Party, Lanham, MD, Scarecrow Press, p. 48.

48. Larus 2012 p. 112.

49. Such as Severe Acute Respiratory Syndrome (SARS); see Southern Weekly 2013 August 1 Understanding the Operation of the Politburo's Standing Committee (Chinese Version), Online. <http://www.infzm.com/content/93040> (accessed 21 January 2016).

50. C. Zhang 2016 The Domestic Dynamics of China's Energy Diplomacy, Singapore, World Scientific Publishing.

51. C.X. Zhou and T.T. Gui 2014 The Duties and Tasks of Small Groups for the Politburo's Standing Committee, Online. <http://news.qq.com/a/20140623/003192.htm> (accessed 21 Janaury 2016).

52. Sullivan 2012 p. 113.

53. Wang 2002 p. 78.

54. Wang 2002 p. 87.

55. Wang 2002 p. 87.

56. Wang 2002 p. 89.

57. Constitution of the People's Republic of China 2004, Online. <http://www.npc.gov.cn/ englishnpc/Constitution/node_2825.htm> (accessed 21 January 2016).

58. The National People's Congress of the People's Republic of China 2016 State Structure of the People's Republic of China, Online. <http://www.npc.gov.cn/englishnpc/ stateStructure/2007-12/06/content_1382098.htm> (accessed 21 January 2016).

59. Sullivan 2012 p. 47.

60. Constitution of the People's Republic of China 2004.

61. Constitution of the People's Republic of China 2004.

62. Larus 2012 p. 122.

63. Zheng 2010.

64. Zheng 2010.

65. Zheng 2010 - see pp. 7-15 (compare with Shambaugh 2008).

66. Zheng 2010 also considers lines of possible future development as revolution/civil war habits of thought and organization are revised over time (pp. 39-40).

67. As a model we get this: as revolution and civil war unfold, (i) received culture informs elite thinking (ii) who construct a party and (iii) engage in state making, and (iv) what they make is a party-state system, (v) thereafter wedded to the pursuit of development. Today the CCP is a large organization: in 2008 it had 73 million members and by 2006 the CCP had 3.6 million organizations, including both Party committees and Party branches at the grass roots level. More than 420,000 firms had established Party organizations. Out of 2.4 million firms in the non-state sector, 178,000 (7.4 per cent) had established Party organizations. In other words, Party organizations have penetrated all forms of firms, institutions and social organisations' (Zheng 2010 p. 4).

68. Zheng 2010 p. 61.

69. Zheng 2010 p. 64.

70. Zheng 2010 p. 73.

71. Zheng 2010 p. 84. 
72. Zheng 2014 Contemporary China: A History since 1978, London, Wiley-Blackwell - see chapter two in particular.

73. Zheng 2010 p. 100.

74. Zheng 2010 p. 101.

75. Zheng 2010 p. 103.

76. Zheng 2010 pp. 104-6.

77. Zheng 2010 p. 108.

78. Zheng 2010 p. 111.

79. Zheng 2010 - Central Party School - part teaching operation for cadres, part research organization and part keeper of ideological line - used by the party to discretely float policy ideas, used by the party to run courses for low level officials, used to teach party leader's doctrines; there are other schools in provinces and cities and counties - some 2000 in all (p. 175).

80. Two issues are particularly important: control of judiciary and control of military - see Zheng 2010 pp. 112-17.

81. Zheng 2010 p. 139.

82. Shambaugh 2008 notes the way the party responded to the unanticipated collapse of the USSR: it upgraded its performance. Others would add that for its public it upgraded its nationalist rhetoric (C.R. Hughes 2006 Chinese Nationalism in the Global Era, London, Routledge; Zhao, Suisheng 2004 A Nation-State by Construction: Dynamics of Modern Chinese Nationalism, Stanford University Press).

83. Zheng 2010 pp. 176-7.

84. Zheng 2010 pp. 176-7.

85. Shambaugh 2008 - CCP looked at the collapse of the USSR and diagnosed a moribund inefficient system; $\mathrm{CCP}$ has looked to upgrade the party apparatus and engage with economic and social reform; plus there is a new stress on nationalism.

86. Notwithstanding numerous signs of local popular dissatisfaction - K. O'Brien and L. Li 2006 Rightful Resistance in Rural China, Cambridge University Press - plus netizens in cities voicing sharp criticisms of the regime (and many other things too).

87. Hughes 2006.

88. That is, Xi's reforms and nationalism are aimed at strengthening the party-state, not changing it (reports began to appear in the Financial Times, Economist, South China Morning Post and so on in mid-2015).

89. Hughes 2006.

90. On this see Gordon White ed. 1988 Developmental States in East Asia, London, Macmillan; Chalmers Johnson 1995 Japan: Who Governs?, New York, Norton; Robert Wade 1990 Governing the Market, Princeton University Press; L. Weiss 1998 The Myth of the Powerless State, Cambridge, Polity.

91. K. O'Brien and L. Li 2006.

92. Noted by X. Ren 2013 pp. 121 et seq.

93. M. Halbwachs (edited by Lewis Coser) 1992 On Collective Memory, Chicago University Press.

94. On this see Patrick Wright 1985 On Living in an Old Country, London, Verso.

95. On the wars, see Dreyer 1995.

96. On the protagonists, see J. Fenby 2005 Generalissimo: Chiang Kai Shek and the China He Lost, London, The Free Press; Short 2004.

97. Zhao 2004 - chapter 1 stresses the 'situational context' of Chinese nationalism, shaped by responses to events, especially wars - thus the Opium Wars feeds into the SelfStrengthening Movement, the (First) Sino-Japanese War feeds into the Boxer Rebellion and the overthrow of the Qing, the Versailles Treaty feeds into the May 4th New Culture Movement, the (Second) Sino-Japanese War feeds into national struggle, the Korean War feeds into consolidation of PRC, and the post-1989 criticisms feed into the CCP self-presentation as the defender of China, wedded to national development.

98. See W.A. Callahan 2006 'History, Identity and Society: Producing and Consuming Nationalism in China' in Critical Asian Studies 38.2 on national humiliation days. 
99. Callahan 2010 pp. 8-14 - these claims produce, after Raymond Williams, a 'structure of feeling'.

100. Christiansen and Rai 1996. 